\title{
Methane emission from a simulated rice field ecosystem as influenced by hydroquinone and dicyandiamide
}

\author{
Xingkai Xu ${ }^{\mathrm{a}, \mathrm{b}, \mathrm{c}, *}$, Yuesi Wang ${ }^{\mathrm{b}}$, Xunhua Zheng ${ }^{\mathrm{b}}$, Mingxing Wang ${ }^{\mathrm{b}}$, \\ Zijian Wang ${ }^{\mathrm{a}}$, Likai Zhou ${ }^{\mathrm{c}}$, Oswald Van Cleemput ${ }^{\mathrm{d}}$ \\ ${ }^{a}$ SKLEAC, Research Center for Eco-Environmental Sciences, Chinese Academy of Sciences and National Environmental \\ Protection Agency, P.O. Box 2871, Beijing, PR China 100085 \\ ${ }^{\mathrm{b}}$ LAPC, Institute of Atmospheric Physics, Chinese Academy of Sciences, Beijing, PR China 100029 \\ ${ }^{\mathrm{c}}$ Soil Ecology Department, Institute of Applied Ecology, Chinese Academy of Sciences, P.O. Box 417, Shenyang, \\ PR China 110015 \\ ${ }^{\mathrm{d}}$ Laboratory of Applied Physical Chemistry, Faculty of Agricultural and Applied Biological Sciences, University of Ghent, \\ B-9000, Gent, Belgium
}

Received 19 January 2000; accepted 7 July 2000

\begin{abstract}
A simple apparatus for collecting methane emission from a simulated rice field ecosystem was formed. With no wheat straw powder amended all treatments with inhibitor(s) had so much lower methane emission during rice growth than the treatment with urea alone (control), which was contrary to methane emission from the cut rice-soil system. Especially for treatments with dicyandiamide (DCD) and with DCD plus hydroquinone (HQ), the total amount of methane emission from the soil system and intact rice-soil system was $68.25-46.64 \%$ and $46.89-41.78 \%$ of the control, respectively. Hence, DCD, especially in combination with HQ, not only increased methane oxidation in the floodwater-soil interface following application of urea, but also significantly enhanced methane oxidation in rice root rhizosphere, particularly from its tillering to booting stage. Wheat straw powder incorporated into flooded surface layer soil significantly weakened the above-mentioned simulating effects. Regression analysis indicated that methane emission from the rice field ecosystem was related to the turnover of ammonium-N in flooded surface layer soil. Diminishing methane emissions from the rice field ecosystem was significantly beneficial to the growth of rice. (c) 2000 Elsevier Science B.V. All rights reserved.
\end{abstract}

Keywords: Dicyandiamide; Hydroquinone; Interface; Methane; Rice field system; Urea

\footnotetext{
* Corresponding author. Present address: LAPC, Institute of Atmospheric Physics, Chinese Academy of Sciences, Beijing, PR China 100029. Fax: +86-10-62041393.

E-mail address: xingkai_xu@hotmail.com (X. Xu).
} 


\section{Introduction}

Flooded rice soil has been recognized as a relatively important source of atmospheric methane (Khalil and Rasmussen, 1983; Bartlett and Harriss, 1993; Wang, 1999) because it provides the suitable conditions for methanogenesis and large areas of land are given over to rice production due to increasing food demands (Bachelet and Neue, 1993). According to an estimation made by the IPCC (1992), flooded rice soil contributed approximately 12\% (343.64 million metric tons of carbon equivalent, MMTCE) of the total global emission (2863.64 MMTCE) of methane in 1992. Although the increase of the total global emission of methane has slowed in recent years (OECD, 1999), the expansion and intensification of rice cultivation in the world will perhaps induce an increase of methane emission to the atmosphere if current technologies are continued. Rice cultivation in China is a more important agricultural practice relative to other countries in the world, and it has been estimated that methane emission from rice cultivation in China is 76.17 MMTCE year $^{-1}$ (with a range of 65.29-87.06 MMTCE year ${ }^{-1}$ ) (Wang and Shangguan, 1996). It is therefore necessary to explore a much more effective mitigation method following a better understanding of the processes involved in methane emission from rice fields (Neue and Roger, 1993).

In rice fields oxic-anoxic interfaces are found at the floodwater-soil interface and in the rice root rhizosphere, and greater potential for methane oxidation always appears at the two interfaces (Conrad and Rothfuss, 1991; Denier Van der Gon and Neue, 1996; Xu and Zhou, 1999). Approximately $80 \%$ of methane borne in rice fields is consumed by soil methanotrophs before its emission to the atmosphere (Conrad and Rothfuss, 1991; Wassman et al., 1993). Hence, improving methane oxidation potential in rice fields will be a more effective method for controlling its emission to the atmosphere.

Urea (main source) and ammonium sulfate account for $80-90 \%$ of total $\mathrm{N}$ fertilizer consump- tion by rice cultivation (FAO, 1989), and urea is widely used in Chinese agricultural practice and the amount used will further increase in the coming century. At higher levels of applied N, methane emissions from rice fields amended with urea were apparently much higher than those amended with other nitrogen fertilizers (Kimura, 1992; Lindau, 1994). Ammonia formation following the hydrolysis of applied urea can more comprehensively destroy the growth of plant than the accumulation of urea in the urease inhibitor(s)-treated soil (Krogmeier et al., 1989), thereby influencing the formation and oxidation of methane in rice root rhizosphere.

Keerthisinghe et al. (1993) found nitrification inhibitors could significantly reduce methane emission from rice fields. However, Cai et al. (1994) observed that methane emission from rice fields in China was promoted in the presence of nitrification inhibitors. These phenomena were partly related to different kinds of inhibitors and the methods of their application. Even so, little attention has been paid to the synergistic effect of urease inhibitors and nitrification inhibitors on the formation and oxidation of methane in rice root rhizosphere so far.

This paper studied methane emission from a urea- and wheat straw amended rice field ecosystem as influenced by the urease inhibitor hydroquinone (HQ) and nitrification inhibitor dicyandiamide (DCD). The research aim was to find an effective mitigation method for controlling methane emissions from flooded rice fields to the atmosphere.

\section{Materials and methods}

\subsection{Soil}

A surface sample $(0-20 \mathrm{~cm})$ of sandy-loam soil collected from the Agricultural Experimental Station of Ghent University, Belgium, was air-dried, crushed to $<2 \mathrm{~mm}$ and thoroughly mixed for use. 
Its main physical and chemical properties were clay $8.9 \%$, silt $14.9 \%$, sand $76.2 \%$, total $\mathrm{N} 0.15 \%$, available $\mathrm{N} 16.7 \mathrm{mg} \mathrm{kg}^{-1}$, organic $\mathrm{C} 1.75 \%$ and $\mathrm{pH}\left(\mathrm{H}_{2} \mathrm{O}\right) 7.56$.

\subsection{Experiment 1: with no wheat straw powder incorporated into surface layer soil}

Two-kilogram air-dried and 2-mm-seived soil samples were put in each experimental pot, and $1.0 \mathrm{~g} \mathrm{~K}_{2} \mathrm{HPO}_{4}$ and $2.0 \mathrm{~g}$ urea were applied as basal fertilizers before flooding. Seven 20-day-old healthy rice seedlings were transplanted into the pot after 1 day of flooding. The pot experiment was divided into planted and non-planted groups. These two groups all contained four urease/ nitrification inhibitors treatments: urea (U), urea + hydroquinone $(\mathrm{U}+\mathrm{HQ})$, urea + dicyandiamide $(\mathrm{U}+\mathrm{DCD})$ and urea + hydroquinone + dicyandiamide $(\mathrm{U}+\mathrm{HQ}+\mathrm{DCD})$. Each treatment for planted group had 12 replications while that for the non-planted group was three replications. The application rate of HQ and DCD was $0.3 \%$ and $5 \%$ of applied urea $(\mathrm{w} / \mathrm{w})$, respectively (Zhao et al., 1993; Xu et al., 2000). Throughout the period of the experiment the floodwater layer on the surface of soil was $2 \mathrm{~cm}$. At indefinite intervals, a self-made PVC cover covered each experimental pot and was sealed with water for 1.0-1.5 $\mathrm{h}$ until the gas was taken using a $10-\mathrm{ml}$ vacuum tube (Fig. 1). Methane concentration in the gas was determined by a gas chromatograph (GC) with a FID indicator under the following conditions: injector temperature $65^{\circ} \mathrm{C}$, oven temperature $55^{\circ} \mathrm{C}$ and detector temperature $200^{\circ} \mathrm{C}$ (Boeckx et al., 1996). Ammonium-N and (nitrite plus nitrate)-N concentrations in the floodwater were determined by the $\mathrm{MgO}$-Devard alloy procedure (Keeney and Nelson, 1982). Every 20 days the above-ground parts of rice were cut, and methane emissions from the cut rice-soil system was determined with the close PVC method as described above. The fresh weight of aboveground parts of rice was observed until the end of the experiment.

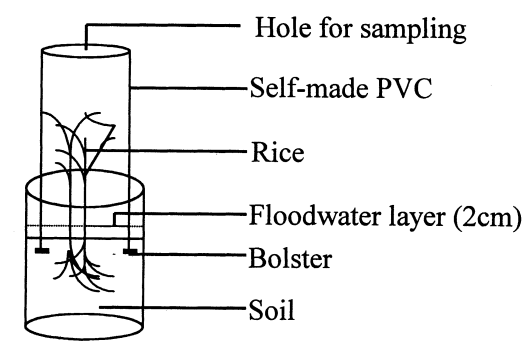

Fig. 1. Simple apparatus for collecting gas samples.

\subsection{Experiment 2: with wheat straw powder incorporated into surface layer soil}

To understand the influences of related inhibitors on methane emission from rice field ecosystem amended with organic matter, wheat straw powder $(10 \mathrm{~g})$ was incorporated into the surface layer soil in each experimental pot before flooding. The pot experiment was also divided into planted and non-planted groups. These two groups only contained three treatments: no urea (CK), urea (U) and urea + HQ + DCD (U + HQ + DCD), and each treatment was replicated three times. Methane emissions from the non-planted soil system and intact rice-soil system, ammonium-N and (nitrite plus nitrate)- $\mathrm{N}$ concentrations in the floodwater were determined during the whole period of cultivation as described in Experiment 1. The fresh weight of above-ground parts of rice was also observed at the end of the experiment.

\subsection{Calculation and statistical analysis}

Methane emissions from the non-planted soil system, intact rice-soil system, and cut rice-soil system were calculated as follows:

$F=\frac{\rho \times(V+10)}{W \times \Delta t}$

where $F$ represents methane emission $\left(\mu \mathrm{g} \mathrm{CH}_{4}\right.$ $\mathrm{kg}^{-1}$ air-dried soil $\left.\mathrm{h}^{-1}\right) ; W$ is the weight of airdried soil in each pot $(\mathrm{kg}) ; V$ is the available 

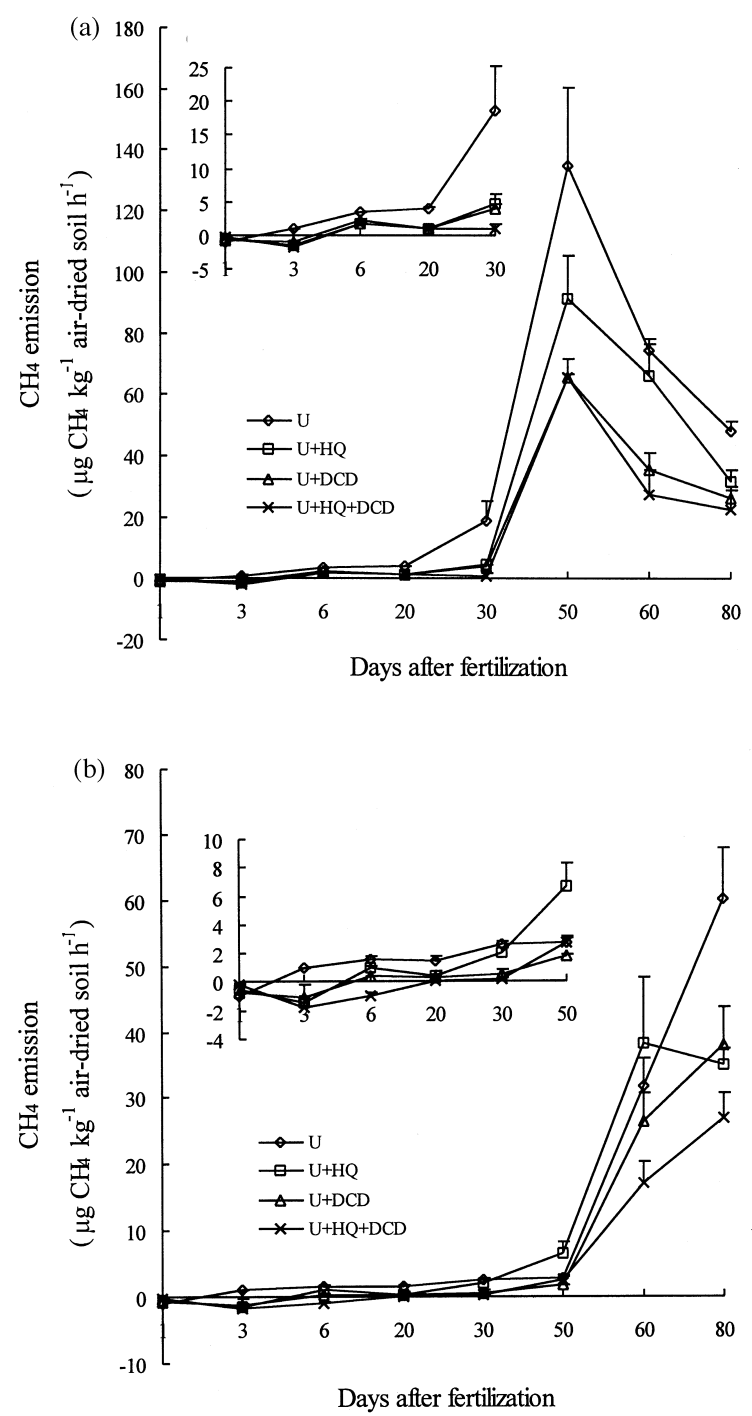

Fig. 2. (a) Dynamic of $\mathrm{CH}_{4}$ emission from intact rice-soil system without applying wheat straw powder (error bar in this figure indicates standard deviation of three replications for each treatment, the same below). (b) Dynamic of $\mathrm{CH}_{4}$ emission from non-planted soil system without applying wheat straw powder.

volume in the self-made PVC (ml); $\rho$ is methane density in a $10-\mathrm{ml}$ vacuum tube determined by $\mathrm{GC}\left(\mu \mathrm{g} \mathrm{CH}_{4} \mathrm{ml}^{-1}\right)$ and $\Delta t$ is the time closed prior to sampling (h).

All data received were subjected to analysis of variance and to Duncan's multiple range tests procedures using the SPSS for windows software package. Multiple linear or curve regressions were used to fit independent variables in the models, which indicated the relationship between methane emission from rice field ecosystems and $\mathrm{N}$ turnover in flooded surface soil and showed the beneficial function of diminishing methane emission from rice field ecosystems to rice growth.

\section{Results and discussions}

\subsection{Dynamic and total amount of methane emission from a simulated rice field ecosystem during rice growth}

In the absence of wheat straw powder, the dynamics of methane emissions from non-planted soil systems and intact rice-soil systems during the whole period of cultivation are shown in Fig. 2a,b. All treatments with inhibitors, especially with DCD and with DCD + HQ apparently could reduce methane emissions from both systems within 80 days after fertilization, and hence significantly eliminated total amount of methane emission, particularly that from intact rice-soil system (Table 1).

In the presence of $\mathrm{DCD}$ and of $\mathrm{DCD}+\mathrm{HQ}$, the fresh weight of above-ground parts of rice always remained much higher during the whole period of cultivation (Fig. 3), thereby indicating the formation of a more highly oxidized rhizosphere. The presence of a more highly oxidized rhizosphere would result in the reduction of methane emission from rice fields to the atmosphere (Denier Van der Gon and Neue, 1996). Keerthisinghe et al. (1993) also reported that nitrification inhibitors could significantly eliminate methane emission from rice fields.

Methane emissions from cut rice-soil systems in any treatment reached the highest value at day 60 after fertilization, when the rice plant entered its vigorous vegetation growth stage (Table 2). Photosynthetically produced carbohydrates by rice plants possibly benefited from methanogensis growth in the rhizosphere. Kimura et al. (1991), Whiting and Chanton (1993) and Thomas et al. 
Table 1

Total amount of $\mathrm{CH}_{4}$ emissions from non-planted soil system and intact rice-soil system without applying wheat straw powder (mg $\mathrm{CH}_{4}$ pot $^{-1}$ ) and their relative values $(\%)^{\mathrm{a}}$

\begin{tabular}{|c|c|c|c|c|}
\hline \multirow[t]{2}{*}{ Treatments } & \multicolumn{2}{|c|}{ Intact rice-soil system } & \multicolumn{2}{|c|}{ Non-planted soil system } \\
\hline & $\begin{array}{l}\text { Total } \mathrm{CH}_{4} \text { emission } \\
\left(\mathrm{mg} \mathrm{CH}_{4} \operatorname{pot}^{-1}\right)\end{array}$ & $\begin{array}{l}\text { Relative values } \\
(\%)\end{array}$ & $\begin{array}{l}\text { Total } \mathrm{CH}_{4} \text { emission } \\
\left(\mathrm{mg} \mathrm{CH}_{4} \operatorname{pot}^{-1}\right)\end{array}$ & $\begin{array}{l}\text { Relative values } \\
(\%)\end{array}$ \\
\hline $\mathrm{U}$ & $190.26(15.9)^{\mathrm{c}}$ & 100.00 & $56.91(7.5)^{\mathrm{c}}$ & 100.00 \\
\hline $\mathrm{U}+\mathrm{HQ}$ & $132.97(10.7)^{\mathrm{b}}$ & 69.88 & $50.84(4.1)^{\mathrm{c}}$ & 89.33 \\
\hline $\mathrm{U}+\mathrm{DCD}$ & $89.22(7.9)^{\mathrm{a}}$ & 46.89 & $38.84(3.6)^{\mathrm{b}}$ & 68.25 \\
\hline $\mathrm{U}+\mathrm{HQ}+\mathrm{DCD}$ & $79.50(10.1)^{\mathrm{a}}$ & 41.78 & $26.54(2.7)^{\mathrm{a}}$ & 46.64 \\
\hline
\end{tabular}

\footnotetext{
${ }^{\mathrm{a}}$ The values in the table and in the parentheses represent the mean and standard deviation of three replicates for each treatment, respectively. Within each column, means followed by different superscript letters are significantly different at $P<0.05$. The same below.
}

(1995) all showed that methane was produced from substances released by rice root.

In the presence of DCD and of $\mathrm{DCD}+\mathrm{HQ}$, methane emissions from the cut rice-soil system within 80 days after fertilization were much higher than in the absence of inhibitor(s) (Table 2). This was the opposite to methane emissions from the intact rice-soil system (Fig. 2a). Accordingly, the reduction of methane emission from flooded rice soil was related to the increased methane oxidation in rice root rhizosphere. DCD, especially in combination with $\mathrm{HQ}$, significantly enhanced methane oxidation in the rice root rhizosphere, particularly between its tillering and booting stages (at 30-80 days after fertilization).

With wheat straw powder amended all treatments had much higher total amount of methane emissions from the non-planted soil system and

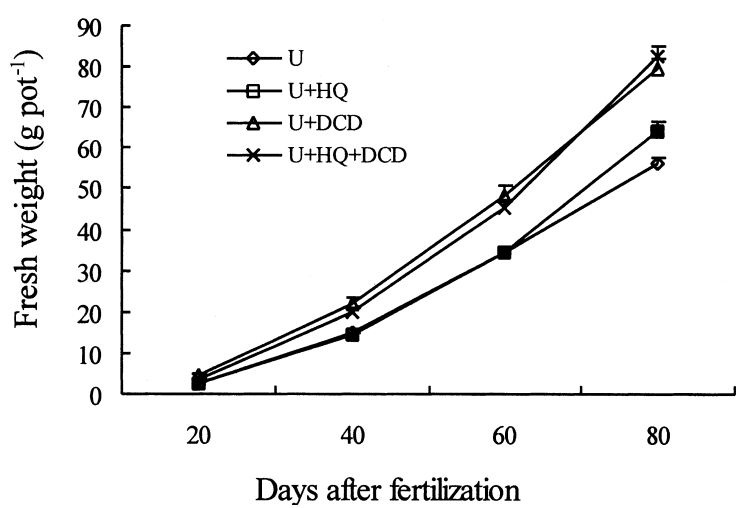

Fig. 3. Dynamic of fresh weight of above-ground parts of rice. intact rice-soil systems (Table 3), as compared to those without wheat straw powder (Table 1). Methane emissions from both systems all increased with time, and reached their maximum values at day 30 after fertilization (Table 4). This is obviously related to the anaerobic decomposition of applied wheat straw powder entering its peak time (Yagi and Minami, 1990; Chidthaisong and Watanabe, 1997). In comparison with the control (no urea), the treatments with urea alone and with $\mathrm{HQ}+\mathrm{DCD}$ could significantly reduce methane emission from intact rice-soil systems but an inhibitory influence of HQ + DCD on methane emissions was not observed (Tables 3 and 4). Although significantly higher methane emissions from the urea-treated soil system at 50-90 days after fertilization was found (Table 4), its total amount in any treatment during the whole period of cultivation had no difference $(P<0.05)$ (Table 3).

If nitrogen was applied it would improve rice growth in the presence of wheat straw powder (data not shown), and a more highly oxidized rhizosphere was promoted. This resulted in a much lower methane emissions from intact rice-soil ecosystems during rice growth (Tables 3 and 4). Anaerobic decomposition of applied wheat straw powder offered some $\mathrm{C}$ sources for soil microbes, and would accelerate the bio-degradation of applied inhibitor(s) in the urea-treated soil to some degree (Hauser and Haselwandter, 1990; Zhao et al., 1993). Therefore, no apparent inhibi- 
Table 2

Dynamic of $\mathrm{CH}_{4}$ emission from cut rice-soil system without applying wheat straw powder $\left(\mu \mathrm{g} \mathrm{CH} \mathrm{kg}^{-1}\right.$ air-dried soil h$\left.{ }^{-1}\right)$

\begin{tabular}{lllll}
\hline Treatments & \multicolumn{4}{l}{ Days after fertilization } \\
\cline { 2 - 5 } & 20 & 40 & 60 & 80 \\
\hline $\mathrm{U}$ & $0.23(0.02)^{\mathrm{a}}$ & $0.64(0.03)^{\mathrm{a}}$ & $2.77(0.33)^{\mathrm{a}}$ & $2.04(0.45)^{\mathrm{a}}$ \\
$\mathrm{U}+$ HQ & $0.33(0.05)^{\mathrm{ab}}$ & $0.48(0.09)^{\mathrm{a}}$ & $7.45(0.07)^{\mathrm{b}}$ & $3.83(1.92)^{\mathrm{ab}}$ \\
$\mathrm{U}+$ DCD & $0.89(0.11)^{\mathrm{c}}$ & $1.21(0.16)^{\mathrm{b}}$ & $7.94(0.62)^{\mathrm{b}}$ & $3.47(0.75)^{\mathrm{ab}}$ \\
$\mathrm{U}+$ HQ + DCD & $0.41(0.04)^{\mathrm{b}}$ & $1.30(0.13)^{\mathrm{b}}$ & $10.93(0.23)^{\mathrm{c}}$ & $6.44(1.35)^{\mathrm{b}}$ \\
\hline
\end{tabular}

tory effects of HQ + DCD on methane emissions from non-planted soil systems and intact rice-soil systems were observed.

The total amount of methane emission from the intact rice-soil system in the control had no apparent variation but significantly decreased in the other two treatments $(P<0.05)$, as compared to that from the non-planted soil system (Table $3)$. Hence, when dissolved methane in the wheat straw-treated soil sharply increased (Nouchi et al., 1994; Wassman et al., 1993), applied N could apparently promote methane oxidation in the rhizosphere of rice through improving rice growth.

\subsection{Methane emission from rice field ecosystem $v$ s. ammonium-N concentration in the floodwater}

The highest value of wheat straw amended ammonium- $\mathrm{N}$ concentration in the floodwater in any treatment appeared at day 30 after fertilization (Table 5), and methane emissions from the soil system and intact rice-soil system also reached the highest values, respectively (Table 4). Regression analysis showed that methane emission from rice field ecosystems amended with wheat straw had a significantly positive exponen- tial relationship with ammonium- $\mathrm{N}$ concentration in the floodwater (Fig. 4). Namely, ammonium-N concentrations in the floodwater less than 1.0-2.0 $\mathrm{mg} \mathrm{N} 1^{-1}$ could result in much lower methane emissions from rice field ecosystems while higher concentrations were more conducive to increasing methane emissions. Hence, under these conditions, the oxidation capacities of methane in flooded rice fields were variable with ammonium$\mathrm{N}$ level in the floodwater. Martin and Ralf (1995) confirmed that ammonium concentrations higher than 5-22 mmol $\mathrm{l}^{-1}$ in the soil aqueous phase inhibited methane oxidation, but also showed that lower concentrations were not inhibitory and even resulted in stimulation.

In the absence of wheat straw, ammonium-N concentration in the floodwater in any treatment decreased by degrees with time (Table 6), apparently different from that in the presence of wheat straw (Table 5). Methane emissions from rice field ecosystems without wheat straw had a significantly negative logarithmic relationship with ammonium concentration in the floodwater (Fig. 5). Accordingly, under this condition methane emissions from rice field ecosystem would decrease with the increase of ammonium concentra-

Table 3

Total amount of $\mathrm{CH}_{4}$ emissions from non-planted soil system and intact rice-soil system amended with wheat straw powder $(\mathrm{g} \mathrm{CH}$ $\operatorname{pot}^{-1}$ ) and their relative values $(\%)$

\begin{tabular}{|c|c|c|c|c|}
\hline \multirow[t]{2}{*}{ Treatments } & \multicolumn{2}{|l|}{ Intact rice-soil system } & \multicolumn{2}{|c|}{ Non-planted soil system } \\
\hline & $\begin{array}{l}\text { Total } \mathrm{CH}_{4} \text { emission } \\
\left(\mathrm{g} \mathrm{CH}_{4} \operatorname{pot}^{-1}\right)\end{array}$ & $\begin{array}{l}\text { Relative values } \\
(\%)\end{array}$ & $\begin{array}{l}\text { Total } \mathrm{CH}_{4} \text { emission } \\
\left(\mathrm{g} \mathrm{CH}_{4} \operatorname{pot}^{-1}\right)\end{array}$ & $\begin{array}{l}\text { Relative values } \\
(\%)\end{array}$ \\
\hline CK & $1.77(0.20)^{\mathrm{b}}$ & 100.00 & $1.95(0.12)^{\mathrm{a}}$ & 100.00 \\
\hline $\mathrm{U}$ & $0.90(0.12)^{\mathrm{a}}$ & 50.85 & $2.08(0.20)^{\mathrm{a}}$ & 106.67 \\
\hline $\mathrm{U}+\mathrm{HQ}+\mathrm{DCD}$ & $0.83(0.15)^{\mathrm{a}}$ & 46.89 & $2.16(0.15)^{\mathrm{a}}$ & 110.77 \\
\hline
\end{tabular}


Table 4

Dynamics of $\mathrm{CH}_{4}$ emissions from non-planted soil system and intact rice-soil system amended with wheat straw powder $\left(\mu \mathrm{g} \mathrm{CH}_{4}\right.$ $\mathrm{kg}^{-1}$ air-dried soil $\mathrm{h}^{-1}$ )

\begin{tabular}{|c|c|c|c|c|c|c|}
\hline \multirow[t]{2}{*}{ Treatments } & \multicolumn{6}{|c|}{ Days after fertilization } \\
\hline & 6 & 14 & 30 & 50 & 70 & 90 \\
\hline \multicolumn{7}{|l|}{ With rice } \\
\hline CK & $3.4(1.1)^{\mathrm{a}}$ & $10.0(2.1)^{\mathrm{a}}$ & $1457.1(110.3)^{\mathrm{b}}$ & $101.9(15.4)^{\mathrm{b}}$ & $19.6(4.0)^{\mathrm{b}}$ & $827.8(106.7)^{\mathrm{b}}$ \\
\hline $\mathrm{U}$ & $3.5(1.8)^{\mathrm{a}}$ & $21.6(5.7)^{\mathrm{a}}$ & $896.0(85.0)^{\mathrm{a}}$ & $81.7(14.2)^{\mathrm{ab}}$ & $6.3(1.7)^{\mathrm{a}}$ & $49.5(9.3)^{\mathrm{a}}$ \\
\hline $\mathrm{U}+\mathrm{HQ}+\mathrm{DCD}$ & $1.7(0.4)^{\mathrm{a}}$ & $16.8(3.1)^{\mathrm{a}}$ & $841.8(86.4)^{\mathrm{a}}$ & $54.1(10.56)^{\mathrm{a}}$ & $4.6(0.2)^{\mathrm{a}}$ & $21.7(13.4)^{\mathrm{a}}$ \\
\hline \multicolumn{7}{|l|}{ No rice } \\
\hline $\mathrm{CK}$ & $2.4(0.9)^{\mathrm{a}}$ & $19.5(4.5)^{\mathrm{a}}$ & $1951.8(275.1)^{\mathrm{a}}$ & $183.4(23.4)^{\mathrm{a}}$ & $15.0(4.0)^{\mathrm{a}}$ & $106.1(11.7)^{\mathrm{a}}$ \\
\hline $\mathrm{U}$ & $2.5(0.8)^{\mathrm{a}}$ & $22.7(4.2)^{\mathrm{a}}$ & $1461.5(205.5)^{\mathrm{a}}$ & $506.4(56.7)^{\mathrm{b}}$ & $31.2(8.1)^{\mathrm{ab}}$ & $148.1(15.7)^{\mathrm{b}}$ \\
\hline $\mathrm{U}+\mathrm{HQ}+\mathrm{DCD}$ & $1.4(0.6)^{\mathrm{a}}$ & $25.8(3.1)^{\mathrm{a}}$ & $1428.3(215.4)^{\mathrm{a}}$ & $467.2(48.5)^{\mathrm{b}}$ & $39.5(7.8)^{b}$ & $168.7(17.1)^{\mathrm{b}}$ \\
\hline
\end{tabular}

tion in the floodwater. The treatments with inhibitor(s), especially with HQ + DCD could significantly enhance ammonium concentrations in the floodwater (Table 6). Hence, methane emission from rice field ecosystems amended with inhibitor(s) significantly decreased (Table 1).

Step regression analysis showed that ammonium-N and nitrite + nitrate- $\mathrm{N}$ concentrations in the floodwater all significantly influence methane emissions from rice field ecosystems.

With wheat straw powder incorporated into the flooded surface layer soil:

$$
\begin{aligned}
& Y=-264+361.95 \times a-1.15 \times b \\
& R^{2}=0.622, P<0.05
\end{aligned}
$$

Without applying wheat straw powder:

$$
\begin{aligned}
& Y=47.78-13.68 \times a-5.55 \times b, \\
& R^{2}=0.633, P<0.01
\end{aligned}
$$

where $Y$ is the methane emission from the rice field ecosystem $\left(\mu \mathrm{g} \mathrm{CH}_{4} \mathrm{~kg}^{-1}\right.$ air-dried soil h$\left.{ }^{-1}\right)$; $a$ and $b$ represent ammonium-N and nitrite + nitrate- $\mathrm{N}$ concentrations in the floodwater $(\mathrm{mg} \mathrm{N}$ $\left.1^{-1}\right)$, respectively.

From Eqs. (1) and (2), the relative importance of ammonium- $\mathrm{N}$ concentration in the floodwater to methane emission from rice field ecosystems amended with wheat straw was higher than that of nitrate + nitrite-N concentration, but this phenomenon in the absence of wheat straw was not found. Hence, methane emission from rice field ecosystem was related to the turnover of

\begin{tabular}{|c|c|c|c|c|c|c|}
\hline \multirow[t]{2}{*}{ Treatments } & \multicolumn{6}{|c|}{ Days after fertilization } \\
\hline & 6 & 14 & 30 & 50 & 70 & 90 \\
\hline \multicolumn{7}{|l|}{ With rice } \\
\hline $\mathrm{CK}$ & $0.36(0.1)^{\mathrm{a}}$ & $1.64(0.1)^{\mathrm{a}}$ & $1.87(0.2)^{\mathrm{a}}$ & $1.07(0.1)^{\mathrm{a}}$ & $0.23(0.1)^{\mathrm{a}}$ & $0.61(0.1)^{\mathrm{a}}$ \\
\hline $\mathrm{U}$ & $0.58(0.1)^{\mathrm{ab}}$ & $1.71(0.2)^{\mathrm{ab}}$ & $3.38(0.3)^{\mathrm{b}}$ & $0.93(0.2)^{\mathrm{a}}$ & $0.33(0.1)^{\mathrm{a}}$ & $0.61(0.1)^{\mathrm{a}}$ \\
\hline $\mathrm{U}+\mathrm{HQ}+\mathrm{DCD}$ & $0.70(0.0)^{\mathrm{b}}$ & $2.45(0.3)^{\mathrm{b}}$ & $4.43(0.4)^{\mathrm{b}}$ & $1.52(0.1)^{\mathrm{b}}$ & $0.70(0.1)^{\mathrm{b}}$ & $0.77(0.1)^{\mathrm{a}}$ \\
\hline \multicolumn{7}{|l|}{ No rice } \\
\hline $\mathrm{CK}$ & $0.47(0.1)^{\mathrm{a}}$ & $1.01(0.3)^{\mathrm{a}}$ & $2.45(0.2)^{\mathrm{a}}$ & $1.20(0.1)^{\mathrm{a}}$ & $0.65(0.1)^{\mathrm{a}}$ & $0.70(0.1)^{\mathrm{a}}$ \\
\hline $\mathrm{U}$ & $0.43(0.2)^{\mathrm{a}}$ & $1.28(0.2)^{\mathrm{a}}$ & $4.08(0.3)^{\mathrm{b}}$ & $2.33(0.3)^{b}$ & $0.75(0.1)^{\mathrm{ab}}$ & $0.75(0.1)^{\mathrm{a}}$ \\
\hline $\mathrm{U}+\mathrm{HQ}+\mathrm{DCD}$ & $0.82(0.1)^{\mathrm{b}}$ & $2.10(0.2)^{b}$ & $3.45(0.3)^{\mathrm{b}}$ & $1.96(0.3)^{\mathrm{b}}$ & $1.12(0.1)^{\mathrm{b}}$ & $0.70(0.1)^{\mathrm{a}}$ \\
\hline
\end{tabular}
ammonium-N in the flooded surface layer soil.

Table 5

Dynamic of $\mathrm{NH}_{4}^{+}-\mathrm{N}$ concentration in the floodwater on the surface of soil amended with wheat straw powder $\left(\mathrm{mg} \mathrm{N} 1^{-1}\right)$ 


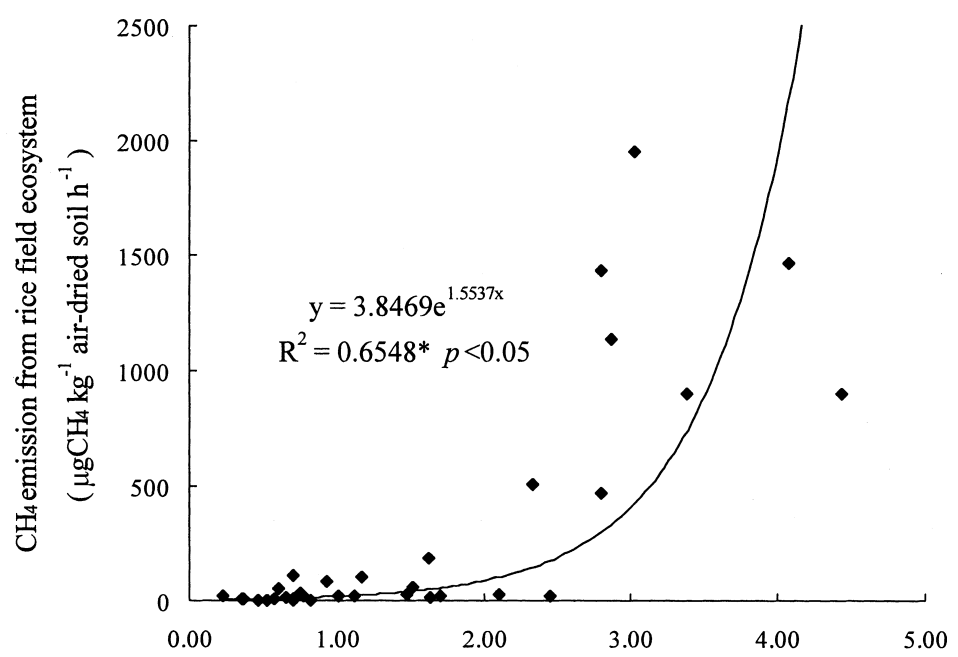

Fig. 4. Relationship between $\mathrm{CH}_{4}$ emission from rice field ecosystem amended with wheat straw and $\mathrm{NH}_{4}^{+}-\mathrm{N}_{\text {concentration in the }}$ floodwater $\left(\mathrm{mg} \mathrm{N}^{-1}\right)$.

The application of organic matter could influence this relation.

3.3. Methane emission from rice field ecosystem vs. fresh weight of above-ground parts of rice

With wheat straw powder incorporated into the flooded surface layer soil:

$Y=-9.50 \times a+2042.40$,

$R^{2}=0.848, P<0.05$
Without applying wheat straw powder:

$$
\begin{aligned}
& Y=-3.87 \times a+395.97 \\
& R^{2}=0.949, P<0.05
\end{aligned}
$$

where $Y$ is the methane emission from the rice field ecosystem ( $\mu \mathrm{g} \mathrm{CH}_{4} \mathrm{~kg}^{-1}$ air-dried soil h${ }^{-1}$ ); $a$ is the fresh weight of above-ground parts of rice $\left(\mathrm{g} \mathrm{pot}^{-1}\right)$.

Eqs. (3) and (4) all showed that methane emissions from rice field ecosystems had a significantly

Table 6

\begin{tabular}{|c|c|c|c|c|c|c|}
\hline \multirow[t]{2}{*}{ Treatments } & \multicolumn{6}{|c|}{ Days after fertilization } \\
\hline & 1 & 3 & 6 & 20 & 60 & 80 \\
\hline \multicolumn{7}{|l|}{ With rice } \\
\hline $\mathrm{U}$ & $1.82(0.1)^{\mathrm{a}}$ & $1.63(0.0)^{\mathrm{a}}$ & $0.93(0.1)^{\mathrm{a}}$ & $1.09(0.1)^{\mathrm{a}}$ & $0.79(0.0)^{\mathrm{a}}$ & $0.75(0.1)^{\mathrm{a}}$ \\
\hline $\mathrm{U}+\mathrm{HQ}$ & $2.57(0.1)^{b}$ & $2.33(0.1)^{\mathrm{b}}$ & $1.17(0.1)^{\mathrm{a}}$ & $0.93(0.2)^{\mathrm{a}}$ & $0.79(0.0)^{\mathrm{a}}$ & $0.84(0.1)^{\mathrm{a}}$ \\
\hline $\mathrm{U}+\mathrm{DCD}$ & $2.49(0.2)^{\mathrm{b}}$ & $2.41(0.1)^{\mathrm{b}}$ & $1.17(0.1)^{\mathrm{a}}$ & $0.93(0.1)^{\mathrm{a}}$ & $1.03(0.2)^{\mathrm{a}}$ & $0.70(0.1)^{\mathrm{a}}$ \\
\hline $\mathrm{U}+\mathrm{HQ}+\mathrm{DCD}$ & $2.75(0.2)^{b}$ & $3.03(0.2)^{\mathrm{c}}$ & $1.54(0.1)^{\mathrm{b}}$ & $1.09(0.1)^{\mathrm{a}}$ & $0.93(0.1)^{\mathrm{a}}$ & $0.65(0.0)^{\mathrm{a}}$ \\
\hline \multicolumn{7}{|l|}{ No rice } \\
\hline $\mathrm{U}$ & $1.82(0.1)^{\mathrm{a}}$ & $1.63(0.0)^{\mathrm{a}}$ & $0.82(0.1)^{\mathrm{a}}$ & $0.54(0.2)^{\mathrm{a}}$ & $0.68(0.1)^{\mathrm{a}}$ & $0.28(0.1)^{\mathrm{a}}$ \\
\hline $\mathrm{U}+\mathrm{HQ}$ & $2.57(0.1)^{b}$ & $2.33(0.1)^{b}$ & $1.01(0.1)^{\mathrm{ab}}$ & $0.67(0.1)^{\mathrm{a}}$ & $0.79(0.2)^{\mathrm{ab}}$ & $0.42(0.1)^{\mathrm{a}}$ \\
\hline $\mathrm{U}+\mathrm{DCD}$ & $2.49(0.2)^{\mathrm{b}}$ & $2.41(0.1)^{\mathrm{b}}$ & $1.28(0.1)^{\mathrm{b}}$ & $0.86(0.1)^{\mathrm{a}}$ & $1.17(0.2)^{\mathrm{b}}$ & $0.70(0.1)^{\mathrm{b}}$ \\
\hline $\mathrm{U}+\mathrm{HQ}+\mathrm{DCD}$ & $2.75(0.2)^{b}$ & $3.03(0.2)^{\mathrm{c}}$ & $1.52(0.2)^{\mathrm{b}}$ & $1.48(0.1)^{\mathrm{b}}$ & $1.12(0.1)^{\mathrm{b}}$ & $0.77(0.1)^{\mathrm{b}}$ \\
\hline
\end{tabular}

Dynamic of $\mathrm{NH}_{4}^{+}-\mathrm{N}$ concentration in the floodwater on the surface of soil without applying wheat straw powder (mg N $\left.1^{-1}\right)$ 


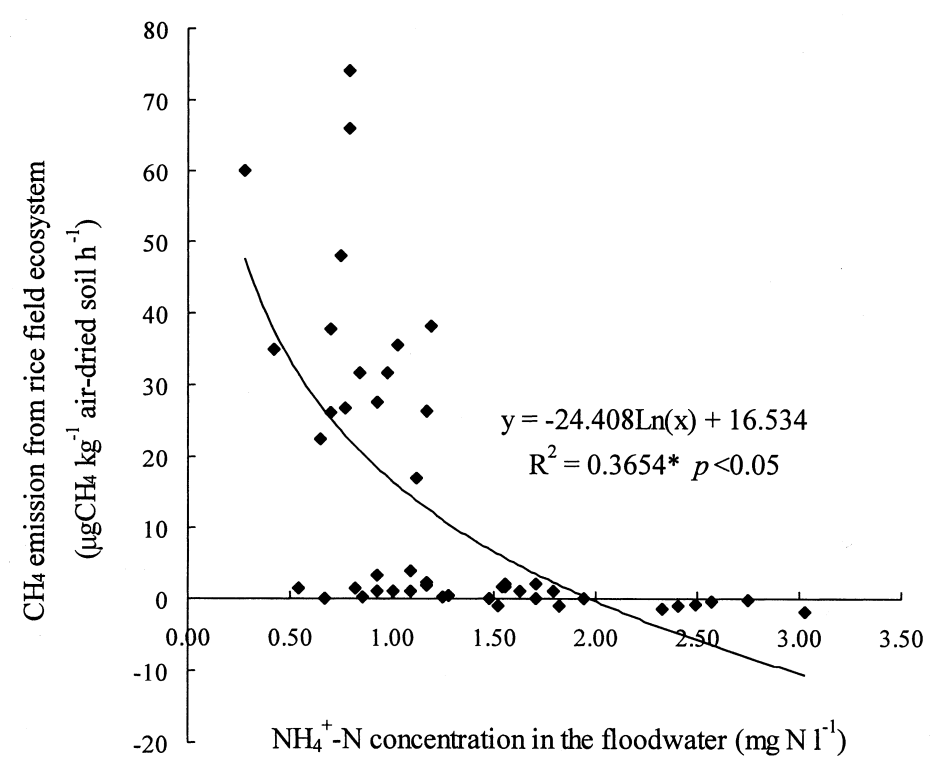

Fig. 5. Relationship between $\mathrm{CH}_{4}$ emission from rice field ecosystem without applying wheat straw and $\mathrm{NH}_{4}^{+}-\mathrm{N}$ concentration in the floodwater.

negative linear relationship with the fresh weight of above-ground parts of rice. Hence, diminishing methane emissions from this wetland rice cultivation was significantly beneficial to the growth of rice. This was in accordance with the results observed by Sass et al. (1990) and by Nouchi et al. (1994).

\section{Conclusions}

In the absence of wheat straw, methane emissions from inhibitor(s)-treated intact rice-soil systems and soil systems appeared to have much lower values during rice growth, which was contrary to methane emissions from the cut rice-soil system. The application of dicyandiamide (DCD) and especially of DCD + hydroquinone (HQ) induced that the total amount of methane emissions from the soil system and the intact rice-soil system was $68.25-46.64 \%$ and $46.89-41.78 \%$ of the control, respectively. Hence, DCD, especially in combination with $\mathrm{HQ}$, could eliminate methane emissions from rice cultivation fields following application of urea. Wheat straw incorporated into flooded surface layer soil significantly weakened the above-mentioned inhibitory effects. Regression analysis indicated that methane emissions from rice field ecosystems were related to the turnover of ammonium- $\mathrm{N}$ in the flooded surface layer soil. Diminishing methane emissions from the wetland rice cultivation was significantly beneficial to the growth of rice.

In recent years, some investigations have showed the right choice of rice variety and irrigation management may result in mitigating or reducing methane emissions from rice cultivation (Singh et al., 1999; Zheng et al., 1999; Xu and Zhou, 1999). Even so, a lot of work regarding the cultivation of rice variety with high root-oxidizing capacity and with high yield need to be done, and some reasonable irrigation management for diminishing methane emissions from rice fields can usually induce an increase in nitrous oxide emission. Thus, a combination of both inhibitors with urea may be an effective mitigation strategy for controlling methane emissions from flooded rice fields to the atmosphere. What's more, this strategy is also beneficial to diminishing the gaseous $\mathrm{N}$ losses out of urea-treated soil-wheat 
systems (Xu et al., 2000) and to the reduction of nitrous oxide emissions from rice fields (date not shown).

\section{Acknowledgements}

Funding for this research was partially provided by 'ABOS' (Ministry of Foreign Affairs, Belgium) and by the National Natural Sciences Foundation of China (Grant No. 29907004). This work was also financially supported by LAPC-KF-2000-08 from the Institute of Atmospheric Physics, Chinese Academy of Sciences, by IAP program 8-2302 and by RCEES-KIP-9901.

\section{References}

Bachelet D, Neue HU. Methane emission from wetland rice areas of Asia. Chemosphere 1993;26:218-237.

Bartlett KB, Harriss RC. Review and assessment of $\mathrm{CH}_{4}$ emissions from wetlands. Chemosphere 1993;26:211-230.

Boeckx P, Van Cleemput O, Villaralvo IDA. Methane emission from a landfill and the methane oxidising capacity of its covering soil. Soil Biol Biochem 1996;28 (10/11):1397-1405.

Cai ZC, Xu H, Zhang HH. Estimate of methane emission from rice paddy field in Taihu Region, China. Pedosphere 1994;4(4):297-306.

Chidthaisong A, Watanabe I. Methane formation and emission from flooded rice soil incorporated with ${ }^{13} \mathrm{C}$-labeled rice straw. Soil Biol Biochem 1997;29(8):1173-1181.

Conrad R, Rothfuss E. Methane oxidation in the soil surface layer of a flooded rice field and the effect of ammonium. Biol Fert Soils 1991;12:28-32.

Denier Van der Gon HAC, Neue HU. Oxidation of methane in the rhizosphere of rice plants. Biol Fert Soils 1996;22: 359-366.

FAO. Fertilizer yearbook. FAO statistical series No. 83. Fertilizer yearbook. vol. 39. Rome, Italy:FAO 1989.

Hauser M, Haselwandter K. Degradation of dicyandiamide by soil bacteria. Soil Biol Biochem 1990;22(1):113-114.

IPCCHoughton JT, Callender BA, Varney SK, editors. Climate change. The supplementary report to the IPCC scientific assessment. Cambridge: Cambridge University Press, 1992:225p

Keeney DR, Nelson DW. Nitrogen - inorganic forms. In: Page AL, Miller RH, Keeney DR, editors. Methods of soil analysis, Part 2. Chemical and microbiological properties. 2nd Madison, Wisconsin, USA: America Society of Agronomy, Inc, 1982:643-687.
Keerthisinghe DG, Freney JR, Mosier AR. Effect of waxcoated calcium carbide and nitrapyrin on nitrogen loss and methane emission from dry-seeded flooded rice. Soil Biol Biochem 1993;16(1):71-75.

Khalil MAK, Rasmussen RJ. Sources, sinks and seasonal cycles of atmospheric methane. J Geophys Res 1983;88:5131-5144.

Kimura M, Murakami H, Wada H. $\mathrm{CO}_{2}, \mathrm{H}_{2}$ and $\mathrm{CH}_{4}$ production in rice rhizosphere. Soil Sci Plant Nutr 1991;37:55-60.

Kimura M. Methane emission from paddy soils in Japan and Thailand. In: Batjies NH, Bridges EM, editors. World inventory of soil emission potentials. WISE report 2. Wageningen: ISRIC, 1992:215.

Krogmeier MJ, Mccarty GW, Bremner JM. Potential phytotoxicity associated with the use of soil urease inhibitors (phenylphosphorodiamidate/N-( $n$-butyl)thiophosphoric triamide). Proc Natl Acad Sci USA 1989;86(4):1110-1112.

Lindau CW. Methane emission from Louisiana rice fields amended with nitrogen fertilizers. Soil Biol Biochem 1994;26(3):353-359.

Martin B, Ralf C. Effect of methane concentration and soil conditions on the induction of methane oxidation activity. Soil Biol Biochem 1995;27:1517-1527.

Neue HU, Roger PA. Rice agriculture: factors controlling emissions. In: Khalil MAK, Shearer M, editors. Global atmospheric methane. NATO ASI/ARW series. 1993:254298.

Nouchi I, Hosono T, Aoki K. Seasonal variation in methane flux from rice paddies associated with methane concentration in soil water, rice biomass and temperature, and its modelling. Plant Soil 1994;161:195-208.

OECD. Environmental Data Compendium. Emissions of greenhouse gases (a), late 1990s, 1999:53 pp.

Sass RL, Fisher FM, Harcombe DA. Methane production and emission in a Texas rice field. Global Biogeochem Cycles 1990;4:47-68.

Singh S, Singh JS, Kashyap AK. Methane flux from irrigated rice fields in relation to crop growth and $\mathrm{N}$-fertilization. Soil Biol Biochem 1999;31:1219-1228.

Thomas KL, Price D, Lloyd D. A comparison of different methods for the measurement of dissolved gas gradients in waterlogged peat cores. J Microbiol Meth 1995;24:191-198.

Wang MX, Shangguan XJ. $\mathrm{CH}_{4}$ emission from various rice fields in P.R. China. Theor Appl Climatol 1996;55:129-138.

Wang MX. Atmospheric chemistry. Beijing: Meteorological Press, 1999:50-305.

Wassman R, Papen H, Rennenberg H. Methane emission from rice paddies and possible mitigation strategies. Chemosphere 1993;26:201-217.

Whiting GJ, Chanton J. Primary production control of methane emission from wetlands. Nature 1993;364:794-795.

$\mathrm{Xu}$ XK, Zhou LK, Van Cleemput O, Wang ZJ. Fate of urea- ${ }^{15} \mathrm{~N}$ in a soil-wheat system as influenced by urease inhibitor hydroquinone and nitrification inhibitor dicyandiamide. Plant Soil 2000;220(1/2):261-270. 
$\mathrm{Xu} \mathrm{XK}$, Zhou LK. Main factors influencing methane oxidation in soil and its control. Ecol Agric Stud 1999;9(2):14-21.

Yagi K, Minami K. Effect of organic matter application on methane emission from some Japanese paddy soil. Soil Sci Plant Nutr 1990;36:599-610.

Zhao XY, Li SD, Zhou LK, Wu GY. Fate of $\left[{ }^{14}\right.$ C $]$ hydro- quinone and $\left[{ }^{15} \mathrm{U}\right]$ urea in a soil-rice system: a pot trial. Soil Biol Biochem 1993;25(1):143-146.

Zheng XH, Wang MX, Wang YS, Shen RX, Li J, Heyer J, Köge M, Papen H, Jin JS, Li LT. Characters of greenhouse gas $\left(\mathrm{CH}_{4}, \mathrm{~N}_{2} \mathrm{O}, \mathrm{NO}\right)$ emissions from croplands of southeast China. World Resource Rev 1999;11(2):229-246. 